\title{
NEVALJANOST POTESTATIVNIH UVJETA U KORIST OBVEZANIKA I PACTUM DISPLICENTIAE
}

U radu se obraduje nevaljanost potestativnih uvjeta u korist uvjetno obvezane strane ugovora te problem iznimnog položaja kupoprodaje na pokus rimskoga prava, tj. ugovora o kupoprodaji s dodanim uglavkom pactum displicentiae prema kojem bi ugovor, odnosno njegov učinak bio ovisan o (ne)zadovoljstvu kupca kupljenom stvari. U prvom dijelu rada izlaže se problematika nevaljanosti potestativnih uvjeta u korist uvjetno obvezanog te priroda iznimaka koje se susreću u izvorima. Nakon toga slijedi raščlamba općih karakteristika uglavka pactum displicentiae, s posebnim osvrtom na činjenicu da je uvjetovana okolnost zadovoljstvo kupca, što bi ga činilo potestativnim uvjetom. Uzimajući u obzir navedeno zatim se obraduju tumačenja romanista kojima se pokušava opravdati postojanje pactum displicentiae. Zaključno se izlaže vlastiti stav o razlozima prihvata valjanosti uglavka.

Ključne riječi: si volam, kupnja na probu, pactum displicentiae, potestativni uvjet, rimsko pravo

\section{UVOD}

Uzgredno, uređujući pitanje kaduciteta kod oporučnih raspolaganja pod uvjetom, u Justinijanovoj konstituciji C. 6, 51, 1, 7 uvjeti su, s obzirom na to ovisi li njihovo ispunjenje o volji uvjetno ovlaštenoga ili ne, ili ovisi samo dije-

* Dr. sc. Marko Sukačić, asistent Pravnog fakulteta Sveučilišta Josipa Jurja Strossmayera u Osijeku, Stjepana Radića 13, Osijek; msukacic@pravos.hr;

ORCID ID: orcid.org/0000-0001-9113-7421 
lom, podijeljeni na kazualne, potestativne i mikstne. ${ }^{1} \mathrm{U}$ konstituciji se condicio potestativa veže uz volju honoratae personae, osobe koja nešto treba steći ako ispuni uvjet. U širem smislu, u romanistici, pojam potestativnih uvjeta protegnut je i na situacije u kojima bi za osobu o čijoj volji ovisi ispunjenje uvjetovane okolnosti nastala određena obveza. Riječ je, u pravilu, o uvjetima pridodanima stipulaciji, no koji su, kako opisuje Pomponije u D. 44, 7, 8 (Pomponius libro 16 ad Sabinum) riječima sub hac condicione 'si volam' nulla fit obligatio, bili nevaljani. Pomponijev navod da obvezivanje promisora pod uvjetom "ako želim" nije bilo valjano potvrđen je i u daljnjim tekstovima koji će biti analizirani u radu, a iz čega je izvedeno opće pravilo da potestativni uvjet ne smije biti formuliran u korist uvjetno obvezane osobe. ${ }^{2}$

$\mathrm{Na}$ širu primjenu pravila od samo stipulacije upućuju Ulpijanov tekst D. 18, 1, 7 pr. (Ulpianus libro 28 ad Sabinum) te konstitucija C. 4, 38, 13 (Imperatores Diocletianus, Maximianus), koji se odnose na kupoprodaju. Problem je, međutim, kako pravilo o nevaljanosti potestativnih uvjeta pomiriti s postojanjem i priznanjem jednog od uglavaka uz kupoprodaju, pactum displicentiae. Ugovaranjem da kupac može jednostrano odustati od kupoprodajnog ugovora u slučaju nezadovoljstva kupljenom stvari, tj. uglavkom čiji se opis nalazi u različitim dijelovima Justinijanove kodifikacije i koji je u srednjem vijeku dobio naziv pactum displicentiae, može se reći da bi stranke sklapale ugovor o kupoprodaji pod uvjetom. ${ }^{3}$ Kako

$1 \quad$ Konstitucijom je uređen problem kadukne imovine, a u tom paragrafu razrađeno je pitanje kako razriješiti situaciju u kojoj je nasljedstvo nasljedniku ostavljeno pod uvjetom gdje je uvjetovana okolnost nasljednikova volja, a on umre prije ispunjenja uvjeta, to jest izražavanja (vlastite) volje. Usp. Frier, B. (ur.); Blume, F. (pr.), Codex Justinianus, vol. 2, Cambridge University Press, Cambridge, 2016., str. 1691.

2 Bechmann, A., Der Kauf nach Gemeinem Recht II, Verlag Von Andreas Deichert, Erlangen, 1884., str. 217; Fitting, H., Zur Lehre vom Kauf auf Probe oder auf Besicht, Zeitschrift für das gesamte Handelsrecht und Wirtschaftsrecht, vol. 2, 1859., str. 233; idem, Zur Lehre vom Kauf auf Probe oder auf Besicht, Zeitschrift für das gesamte Handelsrecht und Wirtschaftsrecht, vol. 5, 1862., str. 139; idem, Ueber den Begriff der Bedingung, Archiv für die civilistische Praxis, vol. 39, 1865., str. 305 - 349; Hasenhöhrl, V., Das österreichische Obligationenrecht in systematischer Darstellung, vol. 1, Manz, Wien, 1892., str. 493 - 494, bilj. 29; Savigny, F. C., System des heutigen römischen Rechts III, Veit und Comp, Berlin, 1840., para. 117, str. 131; Sintenis, C. F. F., Das practische gemeine Civilrecht, Band 2: Das Obligationenrecht, Carl Focke, Leipzig, 1847. str. 594 - 595, bilj. 4. Također vidi djela navedena u sljedećoj bilješci.

3 Diaz Rodriguez, E., De la noción de contrato al pactum displicentiae en derecho romano, Universidad de Oviedo, Oviedo, 1998., str. 220; Kaser, M., Das Römische Privatrecht I, C. H. Beck, München, 1971., str. 561; idem, Das Römische Privatrecht II, C. H. Beck, München, 1971., str. 287; Knellwolf, M., Zur Konstruktion des Kaufes auf Probe, Die Gefallensbedingung und ihr Verhältnis zu Wollensbedingung, Resolutivbedingung und 
je uvjetovana okolnost bila subjektivno zadovoljstvo, odnosno nezadovoljstvo kupca kupljenom stvari, riječ bi bila o potestativnom uvjetu, što je u očitom srazu s naprijed izloženim pravilom. U radu se stoga pokušava dati odgovor na pitanje o tome kako tumačiti dopuštenost pactum displicentiae u kontekstu opće nevaljanosti potestativnih uvjeta. $U$ prvom redu posebno su analizirane svaka od relevantnih kategorija, $s$ jedne strane potestativni uvjeti u rimskom pravu i (ne)mogućnost njihova ugovaranja, te s druge strane pactum displicentiae, nakon čega je pristupljeno raščlambi teza kojima se pokušalo dati objašnjenje valjanosti ovoga uglavka. Konačno, u zaključku je izložen stav autora i ponuđeno rješenje problema.

\section{O POTESTATIVNIM UVJETIMA}

\section{Općenito}

Latinski termin condicio, u općem značenju nagodba, pogodba, zahtjev, prijedlog ili stanje, u pravnom kontekstu označava uvjet, sporedni sporazum ili gotovo svaku odredbu koja je dodana pravnom poslu. ${ }^{4} \mathrm{U}$ doktrini rimskoga, kao i suvremenog građanskog prava, u užem smislu condicio je nuzgredni dodatak pravnome poslu kojim stranke nastup pravnih učinaka povezanih s pravnim poslom čine ovisnim o nastanku ili izvjesnosti nenastanka buduće, neizvjesne činjenice. ${ }^{5}$ Prema tome hoće li učinci ispunjenjem uvjetovane okolnosti nastati ili

Rücktrittsrecht, doktorska disertacija, Schulthess Polygraphischer Verlag AG, Zürich, 1987.; Lardeur, G., Droit Romain: Du Pactum Displicentiae, Droit français: Du contrat d'édition en matière littéraire, doktorska disertacija, Pariz, 1893., Bibliolife (pretisak) 2009.; Mackintosh, J., The Roman Law of Sale with modern illustrations, T. \& T. Clark Law Publishers, Edinburgh, 1907., str. 12 - 13; Misera, K., Der Kauf auf Probe, u: Temporini, H.; Haase, W. (ur.), Aufstieg und Niedergang der römischen Welt, vol. II, 14, 1982., str. 525 - 577; Monier, R., Manuel Élémentaire de Droit Romain, Tome II (Les Obligations), Éditions Domat Montchrestien, Pariz, 1948., str. 166; Pókecz Kovács, A., Rücktrittsvorbehalt und pactum displicentiae (Ulp.D.19.5.20pr.), Revue internationale des droits de l'antiquité, vol. 58, 2011 ., str. 315 - 337; Talamanca, M., Istituzioni di Diritto Romano, Dott. A. Giuffrè Editore, Milano, 1990., str. 592.

4 Divković, M., Latinsko-hrvatski rječnik, Naprijed, Zagreb, pretisak 1990., str. 223; Windscheid, B., Lehrbuch des Pandektenrechts, vol. 1, M. Rütten \& Loening, Frankfurt am Main, 1887., para. 86, str. $264-265$.

5 Heumann, H.; Seckel, E., Handlexikon zu den Quellen des römischen Rechts, Verlag von Gustav Fisher, Jena, 1891., str. 89; Leonard, R., Condicio, u: Paulys Realencyclopädie der classischen Altertumswissenschaft, IV, 1, 1900., str. 844 - 847. Više o dogmatici uvjeta vidi u: Flume, W., Allgemeiner Teil des Bürgerlichen Rechts - Das Rechtsgeschäft, Springer, 
prestati, uvjeti se dijele na suspenzivne ili odgodne ${ }^{6}$, te rezolutivne ili raskidne. ${ }^{7}$ Iako se rimski pravnici klasičnog razdoblja nisu služili nazivima suspenzivan - odgodan (condicio suspensiva) i rezolutivan - raskidan uvjet (condicio resolutiva), prema korištenim frazama smatra se da bi ih de facto razlikovali. ${ }^{8}$ Međutim, pritom je bitno istaknuti da prema šire prihvaćenu mišljenju u suvremenoj romanistici rimski pravnici pravni posao s rezolutivno formuliranim uvjetom zapravo nisu doživljavali kao uvjetovani, već bezuvjetni pravni posao koji će se raskinuti po samom uvjetu. ${ }^{9}$

Uz diobu na odgodne i raskidne, $u$ literaturi se iznose i podjela uvjeta na afirmativne i negativne s obzirom na to treba li se uvjetovana okolnost dogoditi ili ne treba, te na početku navedena dioba na potestativne, kazualne i mikstne uvjete. ${ }^{10} \mathrm{U}$ vezi s potonjom podjelom, kako je uvodno i spomenuto, posebnu pozornost privlače potestativni ili voljni uvjeti u korist obvezane stranke i problem njihove valjanosti, odnosno kada će njihovo ugovaranje uzrokovati nevaljanost posla kojem su pridodani. ${ }^{11}$

Berlin, 1979., str. 677 - 715; Kaser, I, op. cit. u bilj. 3, str. 219 - 225; Honsell, H., Römisches Recht, Berlin, 2005., str. 29 - 31; Zerres, T., Bürgerliches Recht: Eine Einführung in das Zivilrecht und die Grundzüge des Zivilprozessrechts, Springer, Heidelberg, 2010., str. 73; Zimmermann, R., The Law of Obligations, Roman Foundations of the Civilian Tradition, Oxford University Press, Oxford, 1996., str. 716 - 740.

6 Pojam suspenzivnost dolazi od glagola suspendere, odnosno uporabe fraze sub condicione suspensa, npr. u D. 35, 1, 79 pr.: ...Purum legatum est, quia non condicione, sed mora suspenditur... Cf. Effer-Uhe, D. O., Die Wirkung der condicio im römischen Recht, Nomos, Köln, 2008., str. 106 - 113; Peters, F., Die Rücktrittsvorbehalte des römischen Kaufrechts, Böhlau Verlag, Wien, 1973., str. 93 - 124; Wieacker, F., Lex Commissoria: Erfüllungszwang und Widerruf im Römischen Kaufrecht, Springer, Berlin, 1932., str. 19 -31 .

7 Rezolutivni uvjeti, kao i sam pojam rezolutivnost, dolaze iz fraze sub condicione resolvi, vidljive npr. u D. 18, 3, 1: Si fundus commissoria lege venierit, magis est, ut sub condicione resolvi emptio quam sub condicione contrahi videatur... Cf. Kaser, I, op. cit. u bilj. 3, str. 221 et seq.; Peters, loc. cit.; Wieacker, ibid., str. 31 - 36.

8 Zimmermann, op. cit. u bilj. 5, str. 717. Autor je stava kako terminologija kojom su se koristili rimski pravnici odaje dojam da im distinkcija između suspenzivnog i rezolutivnog uvjeta nije bila u potpunosti jasna.

9 Vidi posebice s uputom na daljnju literaturu: Kaser, I, op. cit. u bilj. 3, str. 221 222; Levy, E., Zu den Rücktrittsvorbehalten des römischen Kaufs, u: Levy, E., Gesammelte Schriften, vol. 2, Böhlau, Köln, 1963., str. 262; Peters, op. cit. u bilj. 6, str. 93 - 94.

10 Kaser, I, ibid., str. 222 et seq.; Zimmermann, op. cit. u bilj. 5, str. 722 - 723.

11 Riječ je o problemu koji je zaokupio već pandektiste, a predmetom je razmatranja u njemačkoj pravnoj doktrini do danas. Potestativni uvjet naziva se pritom Wollensbedingung, dok se u francuskoj doktrini, vezano uz Art. 1174 Code civila, naziva 
Nekoliko tekstova iz prvog titula 45. knjige De verborum obligationibus, koji se mogu zajednički analizirati s obzirom na sličan sadržaj, nedvosmisleno izražavaju pravilo da je stipulacija sklopljena pod potestativnim uvjetom u korist uvjetnog dužnika nevaljana:

D. 45, 1, 17 (Ulpianus libro 28 ad Sabinum) Stipulatio non valet in rei promittendi arbitrium collata condicione. ${ }^{12}$

D. 45, 1, 46, 3 (Paulus libro 12 ad Sabinum) Illam autem stipulationem 'si volueris, dari?' inutilem esse constat. ${ }^{13}$

D. 45, 1, 108, I (Iavolenus libro decimo epistularum) Nulla promissio potest consistere, quae ex voluntate promittentis statum capit. ${ }^{14}$

U prvom od fragmenata Ulpijan govori kako je stipulacija kojoj je dodan uvjet u korist promitenda i koji se sastoji u njegovoj prosudbi nevažeća. U drugome Paul nešto konkretnije postavlja pravilo: "Stipulacija izvršena riječima 'ako hoćeš platiti” nevažeća je”, dok u trećemu Javolen tvrdi kako valjano obećanje iz stipulacije ne može biti ono koje će steći učinak samo prema volji dužnika. Za sva tri teksta zajedničko je da na relativno općenitoj razini, ne striktno kazuistički, iznose isti stav o nevaljanosti neodređenog, nesigurnog obvezivanja. Dužnik, odnosno u svim trima primjerima promitend, ne može preuzeti obvezu pod uvjetom da će kasnije osnažiti istu. To bi značilo kako još uvijek nije izrazio svoju namjeru, odnosno želju za sklapanjem ugovora. Također, može se uočiti da tekstovi potječu iz djela klasičnih pravnika 2. i 3. stoljeća, no da su istodobno prva dva sadržani u komentarima Sabinova sustava civilnog prava, što upućuje na ranije formuliranje pravila u okvirima civilnog prava. To bi bilo i logično $\mathrm{s}$ obzirom na to da u ovoj materiji nije bilo znatnijih promjena u razdoblju od civilnog do klasičnog prava.

condition purement potestative. Više o problematičnosti voljnih/potestativnih uvjeta u njemačkoj pravnoj doktrini vidi u: Boemke, B.; Ulrici, B., BGB Allgemeiner Teil, Springer, Berlin, 2009., str. 332; Flume, op. cit. u bilj. 5, str. 684 et seq.; Zimmerman, op. cit. u bilj. 5, str. 745, bilj. 190.

12 D. 45, 1, 17: "Stipulacija nije valjana kad je kao uvjet postavljena volja osobe koja se obvezuje."

13 D. 45, 1, 46, 3: "Međutim, stipulacija sklopljena riječima 'obećavaš li da ćeš dati, ako želiš očito je nevažeća."

14 D. 45, 1, 108, 1: "Nijedno obećanje ne može se sastojati u tome da (obveza) nastane samo prema volji dužnika.” Usp. i prijevod prema Petranović, A., Obligationes Iuris Romani, Pravni fakultet Sveučilišta u Rijeci, Rijeka, 2010., str. 9: "Ne može nastati nikakva obveza (promissio), ako ona ne potječe iz volje (namjere) onoga tko se obvezuje." 
Jedinu razliku u drugospomenutom fragmentu u odnosu na preostale može se zamijetiti u činjenici da se u njemu govori o samom obliku stipulacije, a ne o uvjetu kao takvom. Stipulacija formulirana na način: "Obećavaš li da ćeš platiti, ako hoćeš?”, sadržajno je potestativno uvjetna, ali to nije izraženo kao u ostalim dvama primjerima. Drugocitirani fragment više govori o formi stipulacije, a ne o njezinu uvjetovanju, iako je na taj način ona posredno uvjetovana. Odredba "ako želim", naime, onemogućava pravilno formiranje intencije formule te stoga otpada i mogućnost podizanja tužbe na temelju takve stipulacije. ${ }^{15}$

Šireg značenja, prema smještanju teksta u sedmi titul 44. knjige pod naslovom De obligationibus et actionibus, u kojem su sadržane opće odredbe o obvezama, Pomponijev je tekst D. 44, 7, 8, koji se također odnosi na stipulaciju: ${ }^{16}$

D. 44, 7, 8 (Pomponius libro 16 ad Sabinum) Sub hac condicione 'si volam' nulla fit obligatio: pro non dicto enim est, quod dare nisi velis cogi non possis; nam nec heres promissoris eius, qui numquam dare voluerit, tenetur, quia haec condicio in ipsum promissorem numquam exstitit. ${ }^{17}$

Pomponije govori da je potestativno formulirana obveza kod koje dužnik određuje hoće li izvršiti istu ništetna. Obveza pod uvjetom 'ako hoću', odnosno 'ako hoćeš', nevaljana je i nikad nije ni nastala jer se takvog dužnika ne može prisiliti na ispunjenje uvjetno preuzete obveze. Zaključak o nevaljanosti ugovora razumljiv je jer je za nastanak utužive obveze nužno postojanje pravno oblikovanih mehanizama prisilnog izvršenja preuzete obveze koju dužnik ne želi svojevoljno ispuniti. Ako ga se ne može tužiti na njezino ispunjenje, onda se ne može reći ni da postoji valjana civilna obveza.

Razlog negativnog stava prema potestativnim uvjetima u korist uvjetno obvezane strane prema tome može se prepoznati u činjenici da uvjetno obvezani još uvijek nije izrazio svoju nedvosmislenu volju za postizanjem učinaka pravnog posla jer on praktički može neispunjenjem uvjeta kad god želi odustati od ugovora. Drugim riječima, potestativnim se uvjetom uvjetnom dužniku omogućuje povlačenje prvotno izražene namjere, što ga previše privilegira u odnosu

15 Vidi posebice Knellwolf, op. cit. u bilj. 3, str. 26-27.

16 Tekst potječe iz 16. knjige Pomponijeva komentara ad Sabinum, koja je prema Lenelu naslovljena De iure dotium, a odnosio bi se najvjerojatnije na ustanovljenje obveze povrata miraza uvjetnom stipulacijom. Usp. Lenel, O., Paligenesia Iuris Civils, vol. 2, Bernhard Tauchnitz, Leipzig, 1889., str. 122 - 123.

17 D. 44, 7, 8: 'Obveza pod uvjetom 'ako hoću' je ništetna; smatra se kao da nije ni ugovoreno ono što se od tebe ne može (pravnim sredstvima) potraživati ako ti to nećeš dati. Naime, niti je nasljednik onoga koji nikada nije htio dati odgovoran jer ovaj uvjet nikad nije bio valjan ni prema samom promitendu." Vidi više o fragmentu u: Knellwolf, op. cit. u bilj. 3, str. 27. 
na drugu stranu, uvjetnog vjerovnika. U biti, potestativno obvezivanje dužnika narušava konstrukciju obveze kao vinculum iuris. ${ }^{18}$ Naime, ako dužnik može kad god želi dovesti do izjalovljenja uvjeta, tj. do rezultata kao da ugovor nikad nije sklopljen, iako je isti nedvojbeno sklopljen, gubi se smisao obveze te je stoga i razumljivo da su potestativni uvjeti u korist obvezanika smatrani nevaljanima.

Iznimka od pravila, iako samo formalno, bio bi slučaj negativnog potestativnog uvjeta, formuliranog kroz primjer si Capitolium non ascenderis, odnosno situaciju u kojoj se dužnik obvezuje da će platiti ugovornu kaznu ako ne posjeti Kapitolij, kao primjerice u sljedećem tekstu:

D. 45, 1, 27, I (Pomponius libro 22 ad Sabinum) Si stipulatus hoc modo fuero: 'si intra biennium capitolium non ascenderis, dari?', non nisi praeterito biennio recte petam. ${ }^{19}$

U fragmentu Pomponije navodi da ako se netko obveže da će dati, platiti određenu svotu ako ne posjeti Kapitolij u roku od dvije godine, nije ga moguće tužiti dok ne proteknu dvije godine u kojima je mogao posjetiti Kapitolij. Riječ je o valjanoj obvezi iako bi se u riječima si Capitolium non ascenderis ${ }^{20}$ mogao prepoznati potestativni uvjet s obzirom na to da (ne)posjećivanje Kapitolija isključivo ovisi o volji dužnika. Pritom bi bila riječ o odgodnom uvjetu; ako dužnik posjeti Kapitolij, uvjet se izjalovio i osnovna obveza prestaje; a ako ga ne posjeti, uvjet je ispunjen, suspendirana obveza počinje proizvoditi pravni učinak i dužnik će morati dati ono na što se obvezao.

Fraza si Capitolium non ascenderis istodobno ima i oblik "neprave" ugovorne kazne, jer je dužnik dužan platiti kaznu ako ne ispuni određenu činidbu, i uvjeta, jer je neispunjenje te činidbe formulirano kao dio uvjetovane okolnosti. Kako je i u literaturi izloženo, pri tome se riječi si Capitolium non ascenderis mogu tumačiti kao potestativni uvjet $\mathrm{u}$ korist uvjetno obvezanog. ${ }^{21}$ Neispunjenje uvjetovane činidbe može se promatrati kao izraz volje dužnika; on svojim neispunjenjem prakticira "potestativno" pravo dugovati ugovornu kaznu te posljedično prefor-

18 Definicija obveze kao pravne veze obligatio est iuris vinculum dolazi iz Justinijanovih Institucija, Inst. 3, 13 pr. Vidi više u: Birks, P., The Roman Law of Obligations, OUP, Oxford, 2014, str. 2 - 26; Falcone, G., Obligatio est iuris vinculum, G. Giappichelli, Torino, 2003.; Kaser, I, op. cit. u bilj. 3, str. 401 et seq.; Zimmermann, op. cit. u bilj. 5, str. 1 et seq.

19 D. 45, 1, 27, 1: “Ako se obvežem stipulacijom: 'obećavaš li da ćeš (nešto) dati ako ne posjetiš Kapitolij u roku od dvije godine', ne mogu koristiti tužbu dok dvije godine nisu prošle."

20 Može se pronaći i u D. 45, 1, 27, 1 (Pomponius libro 22 ad Sabinum); D. 45, 1, 99 (Celsus libro 38 digestorum) i D. 45, 115, 1 (Papinianus libro secundo quaestionum).

${ }^{21}$ Knellwolf, op. cit. u bilj. 3, str. 34 - 38; Savigny, op. cit. u bilj. 2, para. 117, str. 129 131. 
mulirati odnos s vjerovnikom u dugovanje kazne, umjesto ispunjenja prvotno ugovorene činidbe posjećivanja Kapitolija.

U činjenici da iz neispunjenja uvjetovane okolnosti proizlazi glavna obveza, plaćanje kazne, proizlazi i glavna sadržajna razlika glede ugovora sklopljenog pod ovako koncipiranim uvjetom od redovitih potestativnih uvjeta, kod kojih ispunjenje uvjeta ovisi samo o dužniku. Naime, kod redovitog potestativnog uvjeta obvezanik u slučaju da ne ispuni uvjet, ili ga ispuni ako je riječ o negativno postavljenom uvjetu, ne bi bio dužan učiniti ništa drugo, dok je kod "neprave" ugovorne kazne riječ o dvjema činidbama od kojih on sam može odabrati koju će izvršiti (ima facultas alternativa); a ako to sam ne odluči, vjerovnik će ga tužiti na ispunjenje jedne, unaprijed točno određene činidbe. U svakom slučaju postoji jedna utuživa, sigurna obveza koja će se moći sudskim putem ostvariti ako dužnik ne učini ništa.

Uz to, kako ističe Knellwolf, razlika se može uočiti i u činjenici da je neposjećivanje Kapitola izvršiva, vanjski vidljiva radnja koja zahtijeva određenu (ne) aktivnost uvjetno obvezanoga, odnosno ona se ne pokazuje u pukom izražavanju volje, kao što je riječ u naprijed citiranim tekstovima koji sadržavaju formulu 'si volueris' i slično. ${ }^{22}$ Međutim, smatramo da ipak ne treba preusko tumačiti frazu 'si volueris' tako da se odnosi samo na slučajeve pukog izražavanja volje riječima ili znakovima, već tako da bi se volja mogla izražavati i kroz određene čine. Bitan element razlikovanja koji bi trebalo uzeti u obzir jest to da se fraza si $\mathrm{Ca}$ pitolium non ascenderis u izvorima ne uspoređuje niti se naziva uvjetom. Slijedom navedenog, ugovorna kazna si Capitolium non ascenderis bila bi samo formalno usporediva s potestativnim uvjetom te je ne bismo isticali kao pravu iznimku od pravila o nevaljanosti potestativnih uvjeta u korist uvjetno obvezanoga kod jednostrano obvezujućih ugovora.

\section{Potestativni uvjet kod sinalagmatičnih ugovora}

Unatoč pretpostavljenom općem značenju D. 44, 7, 8 može se postaviti pitanje kakva je bila situacija s potestativnim uvjetima u korist uvjetno obvezane strane kod sinalagmatičnih, tj. potpuno dvostrano obvezujućih ugovora. ${ }^{23}$ Odgovor na to pitanje glede emptio venditio nedvosmisleno daje konstitucija C. 4, 38, 13

22 Cf. Knellwolf, op. cit. u bilj. 3, str. $36-37$.

23 O pojmu synallagma i sinalagmatičnim ugovorima vidi: Bechmann, A., Der Kauf nach Gemeinem Recht, I, 1876., str. 568 - 607; De Francisci, P., Synallagma, I, Mattei \& C., Pavia, 1913.; idem, Synallagma, II, Mattei \& C., Pavia, 1916.; Zimmermann, op. cit. u bilj. 5 , str. $1-34$. 
s kraja 3. stoljeća, međutim, prema kronološkom prioritetu te složenosti, prvo ćemo uputiti na Ulpijanovu raspravu također u vezi s ugovorom $\mathrm{u}$ kupoprodaji:

D. 18, 1, 7 pr. (Ulpianus libro 28 ad Sabinum) Haec venditio servi 'si rationes domini computasset arbitrio' condicionalis est: condicionales autem venditiones tunc perficiuntur, cum impleta fuerit condicio. Sed utrum haec est venditionis condicio, si ipse dominus putasset suo arbitrio, an vero si arbitrio viri boni? Nam si arbitrium domini accipiamus, venditio nulla est, quemadmodum si quis ita vendiderit, si voluerit, vel stipulanti sic spondeat 'si voluero, decem dabo': neque enim debet in arbitrium rei conferri, an sit obstrictus. Placuit itaque veteribus magis in viri boni arbitrium id collatum videri quam in domini. Si igitur rationes potuit accipere nec accepit, vel accepit, fingit autem se non accepisse, impleta condicio emptionis est et ex empto venditor conveniri potest. ${ }^{24}$

U tekstu se obrađuje problem valjanosti ugovora o prodaji roba sklopljenog uz poseban sporazum si rationes domini computasset arbitrio, što se može prevesti “ako je on (rob) izvršio obračun po nahođenju gospodara, odnosno na gospodaru zadovoljavajući način". ${ }^{25}$ Stranke su se očito dogovorile o predmetu, robu, i cije$\mathrm{ni}^{26}$, no kako je vjerojatno bila riječ o robu koji je vodio gospodareve poslove ili je imao pekulij te je samostalno upravljao dijelom gospodareve imovine povodom koje je trebao položiti račune ${ }^{27}$, prodavatelj si je kao gospodar roba zadržao pravo

24 D. 18, 1, 7 pr.: "Prodaja roba 'ako je izračunao račune po nahođenju gospodara' je uvjetna; uvjetna kupoprodaja postaje perfektna tek kad je uvjet ispunjen. Odnosi li se spomenuti uvjet na gospodarevo osobno zadovoljstvo ili na zadovoljstvo poštenog građanina? Ako prihvatimo prvu interpretaciju, kupoprodaja je ništetna, kao što bi bila u slučaju gdje bi čovjek stvar prodao, ako bi tako odlučio, ili ako bi obećao u stipulaciji: 'Dat ću ti deset ako hoću'; ne može biti ostavljeno na odluku ugovornoj strani je li vezan obvezom ili ne. Dakle, raniji su pravnici zaključili da se to odnosi na prosudbu poštenog čovjeka, a ne na prosudbu samog gospodara (roba). Stoga, ako su računi prihvatljivi, ali ih je on odbio, ili ih je zapravo prihvatio ali se pretvarao da ih odbija, uvjet dodan kupoprodaji bi bio ispunjen i prodavatelj bi mogao biti tužen s tužbom iz kupoprodaje."

25 Prema Watson, A. (ur.), The Digest of Justinian, vol. 1, University of Pennsylvania Press, Philadelphia, 1985., engleski prijevod navedenog dijela glasi: “...if he shall have settled his accounts to his master's satisfaction..." Cf. Knellwolf, op. cit. u bilj. 3, str. 25 i literaturu koju autor navodi.

26 O problemu neodređene cijene i njegova razgraničenja od situacije prodaje pod potestativnim uvjetom opširnije vidi u: Daube, D., Certainty of Price, u: Daube, D. (ur.), Studies in the Roman Law of Sale, Oxford University Press, Oxford, 1959., str. 22; Du Plessis, H., The Unilateral Determination of Price in Roman law, Fundamina: A Journal of Legal History, vol. 18, br. 1, 2012., str. 15 - 31.

27 Više o dužnosti polaganja računa vidi u: Buckland, W. W., The Roman Law of Slavery: The Condition of the Slave in Private Law from Augustus to Justinian, Cambridge University Press, Cambridge, 1908., str. 159 - 238; Hamza, G., Zur Frage der gewi- 
da prvo provjeri je li obračun bio u redu. Prema navedenim riječima ugovor bi bio sklopljen pod odgodnim uvjetom čije je ispunjenje ovisilo o zadovoljstvu uvjetno obvezane strane.

Da je riječ o uvjetu, nedvojbeno proizlazi i iz početne rečenice Haec venditio servi 'si rationes domini computasset arbitrio' condicionalis est, pri čemu se može podsjetiti na činjenicu da su rimski pravnici pod pojmom condicio podrazumijevali odgodno postavljeni uvjet. Dodatno, s obzirom na to da su kod kupoprodaje obje strane istodobno bile i vjerovnik i dužnik, pri čemu je prodavatelj koji treba odlučiti o ispunjenju uvjeta bio dužnik u vezi ispunjenja obveze predaje roba, uvjet formuliran na prikazani način može se tumačiti kao potestativni uvjet u korist uvjetno obvezanog. Zbog toga je uglavak bio i predmetom detaljnije Ulpijanove raščlambe.

U središtu analize valjanosti sporazuma o uvjetu si rationes domini computasset arbitrio jest pojam arbitrium domini i kako ga tumačiti. Ulpijan je ponudio dva rješenja. Prva bi mogućnost bila da se arbitrium tumači tako da se odnosi na procjenu, odnosno diskrecijsku ocjenu dotičnog gospodara, si ipse dominus putasset suo arbitrio. Ako bi on rekao da obračun nije dobar, bez ikakvog ograničenja i bez obzira na to što bi možda prema procjeni suda i bio zadovoljavajući, neće doći do učinaka ugovora. Kako bi odluka ovisila samo o subjektivnoj ocjeni jedne strane, kupoprodaja bi bila nevaljana. Ulpijan situaciju izjednačava sa stipulacijom si voluero, decem dabo ističući da ugovor ne smije ovisiti o volji dužnika hoće li biti obvezan ili neće (arbitrium rei, ... an sit obstrictus).

Drugo tumačenje koje iznosi Ulpijan jest da odluku donosi uvjetno ovlašteni, ali bi ona po svojem sadržaju trebala odgovarati kriteriju odlučivanja apstraktno određene poštene osobe, si arbitrio viri boni. ${ }^{28}$ Arbitrium boni viri jest klauzula koja se pojavljuje već u 2. st. pr. Kr. kod Katona, u njegovu djelu De agricultura, a u suprotnosti prema arbitratu domini, koju klauzulu vidimo i ovdje. ${ }^{29}$ Prema Kato-

llkürten Stellvertretung im klassischen römischen Recht, Annales U. Sci. Budapestinensis Rolando Eotvos Nominatae, vol. 19, 1979., str. 19 - 42; Kaser, M., Stellvertretung und notwendige Entgeltlichkeit, Zeitschrift der Savigny-Stiftung für Rechtsgeschichte, Romanistische Abteilung, vol. 91, 1974., str. 146 - 204; Klinck, F., Zur Bedeutung des Wortes procurator in den Quellen des klassischen Rechts, Zeitschrift der Savigny-Stiftung für Rechtsgeschichte, Romanistische Abteilung, vol. 124, 2007., str. 32 et seq.

28 Doslovan prijevod arbitrium boni viri jest odluka dobre osobe, dobrog i uzornog građanina, uzornog čovjeka neupitne moralne kvalitete i objektivnosti. Više o frazi u: Wlassak, M., Arbiter, u: Paulys Realencyclopädie der classischen Altertumswissenschaft, II, 1, 1895., str. $412-415$.

29 Cato, De Agri Cultura, 144 - 149. Cf. Karlović, T., Neka razmatranja o actio fiduciae (Cic. De off. 3,17,70), Zbornik Pravnog fakulteta u Zagrebu, vol. 67, br. 3-4, 2017., str. 480. 
novim obrascima ugovora, vezivanjem procjene visine štete, odnosno kvalitete vina kriterijem arbitrium boni viri gospodar je prilikom odlučivanja morao postupati kao bonus vir, idealizirani pošteni čovjek, što bi podrazumijevalo objektivno postavljen standard odgovornosti i mogućnost kontrole takve procjene od strane suda. ${ }^{30} \mathrm{U}$ skladu s time, postupajući in favorem negotii, razumljivo je Ulpijanovo pozivanje na ranije pravnike (veteres), odnosno na rimsku pravnu tradiciju prema kojoj bi se ova odredba ugovora (si rationes domini computasset arbitrio) više tumačila na način da gospodareva odluka mora odgovarati onoj kakvu bi bio donio bonus vir. Ključ prihvaćanja drugog rješenja pritom je u zadnjoj rečenici paragrafa, prema kojoj, ako gospodar ne prihvati obračun, a mogao ga je prihvatiti ili je zadovoljan obračunom, no pretvara se kao da nije, smatrat će se da je uvjet ispunjen i druga strana (kupac) moći će ga tužiti sa actio empti.

U okviru rasprave o potestativnim uvjetima samo drugo tumačenje dovodi do prihvatljivog rješenja. U prvom primjeru prodaja je ništetna jer bi bilo nedopustivo ugovoriti da sam dužnik odluči je li obvezan izvršiti svoju obvezu ili nije. Misao vodilja jest da osoba koja je dužnik, odnosno koja je u obvezi, ne može samostalno odlučiti je li zaista u obvezi ili nije. Međutim, kao što je vidljivo kroz dva Ulpijanova tumačenja, narav i učinak na prvi pogled potestativnog uvjeta $u$ korist uvjetno obvezanog može ovisiti i o interpretaciji uvjetnog sadržaja. Ono što bi se izvorno moglo tumačiti kao potestativni uvjet uključivanjem kriterija bonus vir postaje kazualnim uvjetom. U ovom primjeru tako više nije relevantno isključivo zadovoljstvo gospodara, već učinak pravnog posla ovisi o izvedbi roba (obračun) i zahtjevima prosudbe bonus vir na način da bi zapravo bilo isto je li procjena povjerena gospodaru ili trećoj osobi. Riječ je o činjenicama koje izlaze izvan voljne sfere gospodara te se ne može više govoriti o pravom potestativnom uvjetu u korist uvjetno obvezane strane. Situacija je donekle usporediva s mogućnošću objektivnog uvjetovanja kupnje na pokus, poput kupnje vina emptio ad gustum, kod koje kupac može odustati od kupoprodajnog ugovora ako je vino

30 Frier, B., Roman Law and the Wine Trade: The problem of 'Vinegar Sold as Wine', Zeitschrift der Savigny-Stiftung für Rechtsgeschichte, Romanistische Abteilung, vol. 100, 1983., str. 282; Jakab, E., Risikomanagement beim Wienkauf, Periculum und Praxis im Imperium Romanum, C. H. Beck, München, 2009., str. 62; Watson, A., The Law of Obligations in Late Roman Republic, Clarendon Press, Oxford, 1965., str. 96. Za tumačenje kako arbitrium boni viri ne govori o objektivnoj procjeni, vidi Harder, M., Weinkauf und Weinprobe im römischen Recht, u: Lutter, M. et al. (ur.), Festschrift für Johannes Bärmann zum 70. Geburtstag, C. H. Beck, München, 1975., str. 23; Olszak, N., Emptio Ad Gustum: La Vente a la Degustation, de l'Antiquite a l'Article 1587 du Code Civil, Tijdschrift voor Rechtsgeschiedenis, vol. 58, 1990., str. 372; Yaron, R., Sale of Wine, u: Daube, D. (ur.), Studies in the Roman Law of Sale, Clarendon Press, Oxford, 1959., str. 75. 
bilo kiselo ili pljesnivo. I u tom slučaju odluka je na kupcu, međutim on je ograničen objektivnim kriterijem, čija se provjera može tražiti sudskim putem, jer je mogao odustati od ugovora samo ako su na vinu postojala neželjena svojstva kiselosti i pljesnivosti, ali ne i ako mu se ne svidi vino. ${ }^{31}$

Nešto kasnije općeniti odgovor na pitanje valjanosti potestativnih uvjeta kod kupoprodaje nalazimo u reskriptu Dioklecijana i Maksimijana upućenu Aureliju Deciju Lollianu:

C. 4, 38, 13 (Imperatores Diocletianus, Maximianus) In vendentis vel ementis voluntatem collata condicione comparandi, quia non adstringit necessitate contrahentes, obligatio nulla est. Idcirco dominus invitus ex huiusmodi conventione rem propriam vel quilibet alius distrahere non compellitur. ${ }^{32}$

U tekstu se uvodno ne navode konkretnije okolnosti u kojima bi mišljenje bilo dano, no prema drugoj rečenici moglo bi se pretpostaviti da je bila riječ o ugovoru koji je sklopljen pod potestativnim uvjetom u korist kupca koji je ispunio uvjet ${ }^{33}$, odnosno odlučio da želi nastanak učinaka ugovora te je zahtijevao ispunjenje obveze i predaju stvari. Odgovor iz carske kancelarije bio je da kupnja pod uvjetom koji bi ovisio samo o volji prodavatelja ili kupca nije valjana. Ratio odluke jest da obveza iz ugovora ne nastaje jer takav ugovor po svojoj prirodi ne obvezuje stranke. ${ }^{34}$ Kao što je i prije istaknuto, bit obveze u tome je da kad ona jednom nastane, stranke su je dužne ispuniti te ako to ne učine, odgovarat će pred sudom. Iz samog pojma obligare, 'vezati', upravo proizlazi da jedna strana veže drugu na ispunjenje onoga što je obećala ili je dužna iz drugog temelja, no ako ta veza nije čvrsta te se drugi može izvući iz nje kad god želi, ne može se

31 Cf. Goldschmidt, J., Der Kauf auf Probe oder Besicht, Zeitschrift für das gesamte Handelsrecht und Wirtschaftsrecht, vol. 1, 1858., str. 73 - 110; Moyle, J. B., The contract of sale in the Civil Law with references to the Laws of England, Scotland and France, Clarendon Press, Oxford, 1892., str. 83; Pennitz, M., Die Gefahrtragung beim Weinverkauf im klassischen römischen Recht, Tijdschrift voor Rechtsgeschiedenis, vol. 62, 1994., str. 296; Wolf, J. G., Error im römischen Vertragsrecht, Böhlau, Köln, 1961., str. 133. Suprotno od toga, Yaron tvrdi: “...one wishes to buy wine according to one's own judgement, and not according to that of some impartial vir bonus..." Yaron, op. cit. u bilj. 30, str. 75 .

32 C. 4, 38, 13: "Obveza u kupoprodajnom ugovoru koja je uvjetovana voljom prodavatelja ili kupca je ništetna jer ona nužno ne obvezuje ugovorne strane. Iz tog razloga, ni vlasnik ni bilo koja druga osoba ne može biti prisiljena prodati svoju stvar sporazumom opisanog sadržaja."

33 Goldschmidt navodi da se fraza condicione comparandi treba tumačiti u tehničkom smislu kao uvjet, o kojem ovisi sklapanje kupoprodaje. Goldschmidt, op. cit. u bilj. 32, str. 278.

34 Usp. Knellwolf, op. cit. u bilj. 3, str. 30. 
smatrati ni da je vezan. ${ }^{35} \mathrm{U}$ tom smislu i ova konstitucija demonstrira nevaljanost potestativnog obvezivanja koje bi se odnosilo na kupoprodaju, ali po njezinu uzoru i na druge sinalagmatične ugovore. Pritom, kao što je vidljivo iz Ulpijanova teksta, iako bi se u određenim slučajevima na prvi pogled moglo ustvrditi da je riječ o nevaljanom, potestativnom uvjetu, kroz tumačenja pravnika neka stranačka rješenja kojima su one modificirale ugovor bila bi dopustiva.

\section{KUPOPRODAJA SKLOPLJENA UZ PACTUM DISPLICENTIAE}

Ugovor o kupoprodaji mogao je biti prilagođen željama ugovornih strana dodavanjem posebnih uglavaka kojima bi one mijenjale uobičajene učinke ugovora. Pravnodogmatski riječ je o uvjetima, no neki od njih su se tako ustalili te su imali specifičan sadržaj da su dobili posebna imena. Najčešće dodavani uglavci uz kupoprodaju su: lex commissoria - sporazum da prodavatelj zadržava pravo odustanka od ugovora ako kupac u određenom roku ne plati kupovninu ${ }^{36}$, in diem addictio - sporazum da prodavatelj ima pravo u ugovorenom vremenskom roku tražiti boljeg kupca ${ }^{37}$, pactum de retroemendo - sporazum da prodavatelj pridržava pravo unutar ugovorenog roka natrag kupiti prodanu stvar ${ }^{38}$, pactum de retrovendendo - sporazum da kupac može unutar ugovorenog roka natrag prodati stvar prodavatelju ${ }^{39}$, te konačno pactum displicentiae, sporazum o kupnji na pokus, o kojem ćemo više reći u nastavku. Osnovni izvor o pactum displicentiae jesu Justinijanove Institucije, u kojima se na njega upućuje sljedećim riječima:

Inst. 3, 23, 4 Emptio tam sub condicione quam pure contrahi potest. sub condicione veluti 'si Stichus intra certum diem tibi placuerit, erit tibi emptus aureis tot'. ${ }^{40}$

35 O pojmu obligare opširnije cf. Birks, loc. cit.; Zimmermann, op. cit. u bilj. 5, str. 1 - 4 .

36 Wieacker, op. cit. u bilj. 6, str. 19.

37 Sieg, H., Quellenkritische Studien zur Bessergebotsklausel (in diem addictio) im römischen Kaufrecht, Friederichsen, de Gruyter \& Co. m.b.h., Hamburg, 1933.

Zulueta, F. de, The Roman Law of Sale, Introduction and Selected Texts, Oxford University Press, Oxford, London, 1945., str. 58.

39 Horvat, M., Rimsko pravo, Pravni fakultet Zagreb, Zagreb, 2002., str. 353 - 354; Petranović, A., Uvjetovani konsenzus i rimska uvjetna kupoprodaja, Zbornik Pravnog fakulteta Sveučilišta u Rijeci, vol. 28, br. 2, 2007., str. 1226 - 1232.

40 Inst. 3, 23, 4: "Kupnja (ugovor o kupnji) se može zaključiti kako pod uvjetom, tako i čisto, bez uvjeta. Pod uvjetom bi bila ovakva kupnja: 'ako ti se Stih do određenog roka dopadne, dobiti (kupiti) ćeš ga za toliko zlatnika.’” (prijevod prema Romac, A., Justinijan, Institucije, Latina et Graeca, Zagreb, 1994., str. 382). 
Tekst postavlja pravilo da se kupnja može zaključiti pod uvjetom i bez uvjeta. Primjer kupoprodaje sklopljene pod uvjetom jest: "ako ti se stvar (u ovom slučaju rob Stih) svidi u ugovorenom roku, kupit ćeš ga za određenu svotu novca". Prema opisu to bi bio odgodni uvjet jer rob još uvijek nije kupljen, odnosno kupac ima određeni vremenski period u kojem može odlučiti želi li kupiti roba ili ne želi. Sve dok ne izrazi zadovoljstvo, neće biti vezan, pa ugovor neće proizvoditi nikakav pravni učinak. ${ }^{41}$

Prema prikazanom fragmentu, te pozivajući se na četiri ranoklasična pravnika - Sabina, Labeona, Melu i Pomponija ${ }^{42}$, Wieacker zaključuje da je pactum displicentiae prvotno bio isključivo koncipiran kao odgodni uvjet. ${ }^{43}$ Međutim, $\mathrm{u}$ Digestama se uglavak većinom susreće u drugom, raskidnom obliku, primjerice poput sljedećeg teksta:

D. 18, 1, 3 (Ulpianus libro 28 ad Sabinum) Si res ita distracta sit, ut si displicuisset inempta esset, constant non esse sub condicione distractam, sed resolvi emptionem sub condicione. $^{44}$

Fragment pripada Ulpijanu i dolazi iz komentara Sabinova sustava civilnog prava, a pojašnjava kako je očito da stvar koja je prodana na način da će se uzeti kao da nije prodana ako se kupcu ne svidi, nije prodana pod uvjetom, podrazumijevajući pod tim suspenzivni uvjet, već će kupnja biti raskinuta pod uvjetom, sub condicione resolvi. ${ }^{45}$ Suvremenom terminologijom, stvar je prodana pod raskidnim uvjetom, no klasična je rimska jurisprudencija opisani oblik rezolutivno uvjetovane kupoprodaje smatrala bezuvjetnom, no kod koje učinci prestaju ispunjenjem uvjeta. ${ }^{46}$

41 Cf. Diaz Rodriguez, op. cit. u bilj. 3, str. 220.

42 Iako Wieacker ne navodi točno tekstove, već samo pravnike, prema analiziranim fragmentima iz Digesta koji se u literaturi općenito uzimaju da se odnose na pactum displicentiae riječ bi bila o D. 18, 5, 6 (Paulus libro secundo ad edictum), za Sabina; D. 19, 5, 20 pr.-1 (Ulpianus libro 32 ad edictum) za Labeona i Melu; i D. 13, 6, 13, 1 (Pomponius libro 11 ad Sabinum) za Pomponija.

43 Wieacker, op. cit. u bilj. 6, str. 23.

44 D. 18,1,3: "Ako je stvar tako prodana da se smatra neprodanom, ako se ne sviđa, očito je da stvar nije prodana pod suspenzivnim uvjetom, već da se ugovor razvrgava pod uvjetom." (prijevod prema Boras, M.; Margetić, L., Rimsko pravo, Pravni fakultet Zagreb, Zagreb, 1980., str. 99).

45 Pókecz Kovács, op. cit. u bilj. 3, str. 320.

46 Windscheid takve uvjete tumači kao dopunske izjave volje, usmjerene na ukidanje učinaka glavne volje, te ih tako razlikuje od suvremenih rezolutivnih uvjeta. Potvrdu pronalazi u opisu rezolutivno uvjetovanih poslova kao negotium purum, qoud sub condicione resolvitur, iz D. 18, 2, 2 (Ulpianus libro 28 ad Sabinum). Cf. Windscheid, B., op. cit. u bilj. 4 , para 86 , str. 264 et seq. 
Pitanje pravne naravi uvjeta i načina njegova postavljanja ključno je u raspravama o karakteru instituta pactum displicentiae. ${ }^{47}$ Međutim, kao što se može iščitati iz citiranih tekstova, rimsko pravo omogućavalo je oba oblika sklapanja kupnje na probu, i kupnju s odgodnim uvjetom, u kojoj je ugovor ovisan o činjenici da je kupac odobrio kupnju, i kupnju s raskidnim uvjetom, u kojoj je ugovor sklopljen, ali može naknadno biti raskinut odlukom kupca. ${ }^{48} \mathrm{U}$ obama slučajevima pactum displicentiae omogućavao je kupcu kao uvjetno ovlaštenoj osobi da sukladno vlastitim kriterijima osnaži ili raskine kupoprodajni ugovor.

U kontekstu rasprave o potestativnim uvjetima te $u$ vezi s mogućnošću interpretacije koju je Ulpijan iznio u D. 18, 1, 7 pr. postavlja se pitanje kvalitete tih kriterija. Prema navedenim tekstovima Inst. 3, 23, 4 i D. 18, 1, 3 (Ulpianus libro 28 ad Sabinum), što potvrđuju i ostali tekstovi u kojima se pactum displicentiae spominje, predviđeni kriterij bio je uvjet sviđanja/zadovoljstva, odnosno nesviđanja/nezadovoljstva. Sviđanje je kod uglavka pactum displicentiae izraženo $\mathrm{u}$ glagolu placere, a nesviđanje u displicere. ${ }^{49}$ Navedene glagole teško je, odnosno kako upućuju i rječnici nemoguće tumačiti kao objektivne kriterije. ${ }^{50}$ Keller, primjerice, tako tvrdi da je kod kupnje na pokus kupac slobodan prihvatiti ili odbiti stvar prema slobodnom nahođenju, pri čemu se to ne može izjednačiti s procjenom dobrog čovjeka: “...das displicere ist in die reine Willkür des Käufers

47 Cf. Knellwolf, op. cit. u bilj. 3, str. 22; Misera, op. cit. u bilj. 3, str. 539 - 559; Zimmermann, op. cit. u bilj. 5, str. 739.

48 Cf. Pókecz Kovács, op. cit. u bilj. 3, str. 320 et sqq.

49 Placeo, koji se prevodi kao 'dopasti se, ugoditi'. Cf. Divković, op. cit. u bilj. 4, str. 799. Engleski prijevod placeo može se pronaći u: Lewis, C. T., An Elementary Latin Dictionary, American Book Company, New York, 1890. (dostupno online). Displicentia, imenica po kojoj je pakt dobio ime, prema Forcelliniju označava animi affectio, qua quis sibi displicet, to jest stanje uma, situaciju koja uzrokuje nezadovoljstvo. $C f$. Facciolati, J.; Forcellini, E., Totius latinitas lexicon, vol. 2. D-K, Baldwin et Cradock, London, 1828., str. 160.

50 Marević placere prevodi kao 'ostaviti dojam, goditi, sviđati se jako', a displicere kao 'ne sviđati se, ne goditi'. Marević, I., Hrvatsko - latinski enciklopedijski rječnik, II. svezak, Školska knjiga, Zagreb, 1997., str. 2473. Psihologijski rječnik ugodu definira kao jedan od polova osnovnih čuvstvenih kvaliteta (drugi pol je neugoda). U stanju ugode čovjek ima potrebu produživanja situacije koja tu ugodu izaziva. Vidi u: Petz, B. et al., Psihologijski rječnik, Slap, Zagreb, 2005., str. 523. Rječnik hrvatskog jezika definira zadovoljstvo kao osjećaj onoga koji je zadovoljan, koji ima ono što želi, kome je želja ispunjena, koji ne traži više od onog što ima, svidjeti se kao ostaviti dobar dojam, a nezadovoljstvo kao stanje onoga koji je nezadovoljan. Cf. Anić, V., Veliki rječnik hrvatskog jezika, Novi Liber, Zagreb, 2009., str. 872, 1516 i 1777. 
gestellt, nicht auf arbitrium viri boni." ${ }^{51}$ Prema izloženom, pactum displicentiae mogao bi se kategorizirati kao čisti potestativni - voljni uvjet.

Subjektivna narav procjene dolazi primjerice do izražaja i u frazi emere nolle u Ulpijanovu fragmentu koji obrađuje srodnu situaciju:

D. 19, 5, 20 pr. (Ulpianus libro 32 ad edictum) Apud Labeonem quaeritur, si tibi equos venales experiendos dedero, ut, si in triduo displicuissent, redderes, tuque desultor in his cucurreris et viceris, deinde emere nolueris, an sit adversus te ex vendito actio. Et puto verius esse praescriptis verbis agendum: nam inter nos hoc actum, ut experimentum gratuitum acciperes, non ut etiam certares. ${ }^{52}$

Ulpijan u tekstu prenosi problem koji je izvorno raspravio Labeon o kupnji konja na pokus kod koje je kupac - akrobatski jahač mogao tri dana besplatno testirati konje, što je on i učinio sudjelujući na natjecanju na kojem je pobijedio. Međutim, potencijalni kupac svejedno je odlučio vratiti konje te je kod Labeona postavljeno pitanje može li ga prodavatelj tužiti tužbom iz kupoprodaje. S druge strane, prema Ulpijanu bi ga trebalo tužiti s actio praescriptis verbis. Opravdanje za to Ulpijan nalazi u činjenici da je među strankama dogovoreno da će jahač besplatno testirati konje, a ne da će i sudjelovati na natjecanju. ${ }^{53}$ Kako ni Ulpijan ni Labeon ne dovode u pitanje povrat konja, može se zaključiti kako nije sporno da ih je kupac mogao po vlastitu nahođenju vratiti.

Ključna je fraza emere nolle, što bi se moglo prevesti kao 'ne željeti kupiti', s obzirom na to da je nolle infinitiv prezenta aktiva glagola nolo i prevodi se kao 'ne željeti' ${ }^{54}$ Kako se spominju želje, riječ je o subjektivnim preferencijama koje nisu podložne objektivnim kriterijima. Na istom tragu je i Lardeurov opći zaključak - pactum displicentiae omogućuje kupcu da samom voljom djeluje destruktivno na

51 Cf. Keller, F. L., Pandekten, II, Bernhard Tauchnitz, Leipzig, 1866., str. 55.

52 D. 19, 5, 20 pr.: "Kod Labeona se raspravlja pitanje, ako bih ti dao na probu moje konje koji su za prodaju i ako ne budeš zadovoljan sa njima da ih vratiš u roku 3 dana, te bi ti kao akrobatski jahač s njima jahao na natjecanju i pobijedio, no ipak ih ne bi želio kupiti, mogu li te tužiti s tužbom iz kupoprodaje. Mislim da je ipak točnije da treba tužiti sa actio praescriptis verbis jer smo ugovorili da konje dobiješ na besplatnu probu, no ne i da se s njima natječeš." (prijevod prema: Karlović, T., Liber casuum, Priručnik za vježbe iz rimskog obveznog prava, Pravni fakultet Sveučilišta u Zagrebu, Zagreb, 2017., str. 145 - 146).

53 Pravo na dobitak se u pravilu veže uz snošenje rizika. Vidi više u: Wacke, A., Dig. 19,5,20pr:: Ein Siegespreis auf fremden Pferden. Zur Gewinn-Ablieferungspflicht beim Kauf auf Probe, Zeitschrift der Savigny-Stiftung für Rechtsgeschichte, Romanistische Abteilung, vol. 119, 2002., str. 371 et seq.

54 Divković, op. cit. u bilj. 4, str. 699. Engleski prijevod glagola nolo može se pronaći u: Lewis, C. T., An Elementary Latin Dictionary, New York, 1890. 
kupoprodajni ugovor zato što mu prodani predmet ne odgovara. ${ }^{55}$ To je jedini uvjet koji je potreban te kupac nije dužan navoditi razloge koji bi pravdali njegov subjektivni stav. Možemo stoga reći da kupac ni ne mora izvršavati ispitivanje ako to ne želi i ne postoji nikakva sankcija za tu njegovu odluku. Učinak ugovora bi ugovaranjem pactum displicentiae postajao ovisnim samo o volji uvjetno ovlaštenog kupca koji je mogao izjaviti da mu se stvar sviđa ili ne sviđa.

\section{OPRAVDANJE VALJANOSTI PACTUM DISPLICENTIAE}

\section{Objašnjenja temeljena na formulaciji sporazuma kao odgodnog uvjeta}

S obzirom na prvotno izloženo pravilo o nevaljanosti zasnivanja obveze pod potestativnim uvjetom $\mathrm{u}$ korist uvjetno obvezanog postavlja se pitanje kako objasniti dopuštenost pactum displicentiae kao upravo jednog takvog uvjeta. Uglavak uredno nalazimo u izvorima rimskog prava te nijedan od klasičnih pravnika u dostupnim tekstovima ne problematizira njegovu valjanost, tako da bi logično rješenje bilo promatrati ga kao iznimku od pravila. Međutim, iz izvora nije jasno vidljivo što bi to opravdalo izuzimanje takve klauzule iz sustava pravila primjenjivih na sve obveze.

Jedno od predloženih rješenja jest da pactum displicentiae ne treba tumačiti kao čisti potestativni uvjet. ${ }^{56}$ Istaknuto mjesto pri tome zauzima Bechmann tumačeći da se ugoda, zadovoljstvo kod pactum displicentiae odnosi isključivo na predmet, objekt kupoprodaje, a ne i na sam kupoprodajni ugovor. ${ }^{57}$ Psihološko zadovoljstvo i užitak u predmetu je motiv, koji nije identičan volji potrebnoj za sklapanje osnovnog kupoprodajnog ugovora kojem je dodan uvjet sviđanja. ${ }^{58}$

55 Cf. Lardeur, op. cit. u bilj. 3, str. 9.

56 Začeci navedenog stava mogli bi se prepoznati u Savignyjevu tumačenju da je kupnja na pokus jedinstvena iznimka od pravila o nevaljanosti potestativnih uvjeta jer kupac može jednostrano raskinuti ugovor, ali samo u pitanju vezanom uz kvalitetu materije. Međutim, sam naziv kupnje na pokus, Kauf ad gustum, kao i navedeni tekstovi, jasno upućuju na to da se on pritom referirao na emptio ad gustum, kupnju vina na pokus kao temelj, a ne na pactum displicentiae, iako su dva instituta zajednički obrađivana $\mathrm{u}$ doktrini $\mathrm{u}$ vezi s kupnjom na pokus. To je bitno jer se raskid ugovora kod emptio ad gustum veže uz kvalitetu objekta, a ne samu volju (sviđanje), te se tada ne može govoriti o čistom voljnom uvjetu i takav uglavak bi razumljivo bio valjan. Cf. Savigny, op. cit. u bilj. 2, para. 117, str. 131. 
Pri razlikovanju dviju volja egzistencija pravnog posla nije uvjetovana voljom za sam pravni posao, već ovisi o subjektivnom stavu prema objektu ugovora. Prema tome, postoji načelna razlika između "sviđanja" i volje; placere je prosudba o objektu, a ne puka izjava volje (u smislu 'si voluerit'). ${ }^{59}$ Kako se ta prosudba, placere, odnosi na jednu vrlo specifičnu okolnost vezanu uz objekt, može se prihvatiti postojanje valjanog uvjetovanog pravnog posla. Za samu teoriju ključna je diferencijacija između dviju volja u psihološkom smislu. Obje volje nastaju unutarnjim procesima u čovjekovu umu te obje postaju pravno relevantne kad budu očitovane prema van ${ }^{60}$, međutim volja za sklapanje ugovora, si voluerit, sadržajno se razlikuje od izvanjskog pokazivanja volje o sviđanju, si placuerit.

Problem, kojeg se dotakao i sam Bechmann, jest pitanje konačnog rezultata. ${ }^{61}$ Praktična razlika u konačnici ne postoji; bio ugovor potestativno uvjetovan na način da uvjetno obvezani osnažuje pravni posao bilo da on ovisi o nezadovoljstvu kupca predmetom, krajnji je rezultat jednak. To posebice dolazi do izražaja zbog činjenice da je nemoguće provesti kontrolu unutarnje volje kupca, što je, na primjer, moguće u slučaju kada bi se volja trebala procijeniti prema kriteriju arbitrium boni viri. Tada se relativno lako može utvrditi je li kupac postupio kako bi postupio treći, pošteni građanin. Unutarnju volju kupca glede toga sviđa li mu se stvar pak nije moguće promatrati i tumačiti sve dok ne bude izražena prema van. Stoga, kupcu se čak i može svidjeti predmet, ali on i dalje može prema van iskazati nezadovoljstvo koje ni koji način neće moći biti osporeno. U navedenom se može uočiti i glavni nedostatak ove teze te je stoga razumljivo da kasnije nije našla pristaše.

Drugo objašnjenje temeljeno na odgodnoj koncepciji, a koje uvažava zabranu potestativnih uvjeta, javlja se u kontekstu rasprava pandektista tijekom 19. stoljeća o pojmu šepavih pravnih poslova, negotium claudicans. ${ }^{62}$ Bit navedene koncepcije jest rastavljanje posla na pojedinačne izjave volje stranaka od kojih svaka ima posebne pravne učinke. Prema toj koncepciji, pri čijem su objašnjenju pactum displicentiae, kupnja na probu i općenito potestativni uvjeti češće korišteni kao primjeri, za nastanak kupoprodaje na probu potrebno je očitovanje volje dviju strana. Volja prodavatelja nije upitna, no problem je na strani kupca koji se obvezao ispuniti obvezu pod potestativnim uvjetom zadovoljstva te će tek

59 Ibid.

60 Cf. Hasenhöhrl, op. cit. u bilj. 2, str. 493 - 494, bilj. 29; Sintenis, op. cit. u bilj. 2, str. $594-595$, bilj. 5 .

${ }^{61}$ Bechmann, II, op. cit. u bilj. 2, str. 217.

62 Vidi Windscheid, B., Lehrbuch des Pandektenrechts, 5. Aufl., Ebner \& Seubert, Stuttgart, 1879., Bd. 1, § 93, str. 266, bilj. 1, Bd. 2, §321, str. 238, bilj. 24; Knellwolf, op. cit. u bilj. 3, str. 68 i literatura koju autor navodi. 
njegovim izražavanjem zadovoljstva objektom doći do nastanka pravnih učinaka ugovora, a ne prethodnim obvezivanjem. ${ }^{63}$

Osnovni primjer šepavog pravnog posla u rimskom pravu bio bi ugovor koji je sklopio maloljetnik bez suglasnosti tutora jer ga pravni posao nije obvezivao do potvrde tutora. ${ }^{64}$ Prema tumačenju pandektista, za drugu stranu, dakle osobu koja bi sklopila posao s maloljetnikom, moglo bi se reći da je sklopila pravni posao pod potestativnim uvjetom si tutor voluerit. ${ }^{65}$ Prema tome, volja koju je maloljetnik izrazio nije izravno uključena u sam ugovor, no o njoj ovisi cjelokupni pravni posao. Sličnost s kupoprodajom na pokus jest u činjenici da postoji obveza jedne i uvjetna sloboda druge ugovorne strane. Zbog toga bi se i kupoprodaja na pokus mogla tumačiti kao šepavi pravni posao, tj. sam je pravni posao nevaljan, ali uvjetno i to samo dok ga kupac ne potvrdi. ${ }^{66}$ Kupčevim će dopuštenjem valjanosti pravnog posla on steći element koji mu je nedostajao te će tako izgubiti svojstvo šepavosti.

Problematičnost tumačenja kupnje na pokus kao šepavog pravnog posla uočava se u izvorima iz kojih se ne može iščitati kako je kod kupoprodaje na pokus s dodanim uglavkom pactum displicentiae riječ o manjkavom pravnom poslu, te bi se moglo ustvrditi da je riječ o projekciji suvremenih postulata na rimsko pravo. Šepavi pravni posao dobiva se tumačenjem izvora na način koji navodi na šepavost, a to je razdvajanje kupoprodaje na emptio i venditio. Kupoprodaja se, međutim, ne sastoji od dvaju elementa; ona je konsenzualni sinalagmatični ugovor te stoga djeluje malo vjerojatnim tumačenje o nedostatku jednog elementa i posljedične šepavosti. ${ }^{67}$

\section{Tumačenja klauzule kao prava na raskid ugovora}

Drugi oblik opravdanja postojanja kupnje na pokus u kontekstu njegove potestativne pravne naravi može se pronaći u tumačenju da uglavak pactum displicentiae predstavlja neuvjetni pravni posao, odnosno da je riječ o uglavku kojim kupac dobiva pravo na jednostrani raskid ugovora. ${ }^{68} \mathrm{Na}$ sljedećem se fragmentu može uočiti prikazani učinak:

63 Knellwolf, ibid.

64 Kaser, I, op. cit. u bilj. 3, str. 76 et seq.

65 Unger, J., Das Versprechen als Verpflichtungsgrund, Zeitschrift für das privat- und öffentliche Recht der Gegenwart, Bd. 1, 1874., str. 367.

66 Knellwolf tu potvrdu naziva dopuštenje. Usp. Knellwolf, op. cit. u bilj. 3, str. 70.

67 Uz to može se uputiti i na Flumeovu kritiku artificijelnosti argumentacije pandektista u ovom pitanju. Cf. Flume, op. cit. u bilj. 3, str. $684-685$.

68 Knellwolf, op. cit. u bilj. 3, str. 127 - 128; Peters, op. cit. u bilj. 6, str. 83 et seq. 
D. 20, 6, 3 (Ulpianus libro octavo disputationum) Si res distracta fuerit sic, nisi intra certum diem meliorem condicionem invenisset, fueritque tradita et forte emptor, antequam melior condicio offeretur, hanc rem pignori dedisset, Marcellus libro quinto digestorum ait finiri pignus, si melior condicio fuerit allata, quamquam, ubi sic res distracta est, nisi emptori displicuisset, pignus finiri non putet. ${ }^{69}$

Ulpijan je obrađivao pitanje uglavka in diem addictio - pridržaja prodavatelja da traži boljeg kupca, ali se dotaknuo i uglavka pactum displicentiae. Pritom je uputio na Marcela, prema kojemu pignus osnovan u periodu testiranja objekta neće prestati postojati povratom kupljene stvari prodavatelju zbog nezadovoljstva. Drugim riječima, raskid ugovora zbog raskidnog uvjeta djelovat će isključivo ex nunc jer prodavatelj neće biti vraćen u poziciju u kojoj je bio prije sklapanja uvjetovanog kupoprodajnog ugovora. Prodavatelj će stoga dobiti natrag stvar opterećenu založnim pravom. Prema tome, po Ulpijanu i Marcelu kupnja na pokus s raskidnim uvjetom neće imati ex tunc učinak zbog nezadovoljstva kupca, već isključivo djelovanje pro futuro, što je sadržajno identično suvremenom raskidu ugovora. Pravni učinci koje je pravni posao proizveo u vremenu do ispunjenja uvjeta i dalje ostaju.

U navedenom smislu je i Knellwolf ustvrdio da pactum displicentiae nije uvjet, već sporedni sporazum koji kupcu daje pravo na jednostrani raskid ugovora ako mu se objekt kupoprodaje ne svidi u ugovorenom razdoblju, što naziva $M i$ ssfallensvorbehalt. ${ }^{70}$ Prema tom prikazu izbjegava se primjena potestativnog uvjeta u korist uvjetno obveznog jer se pactum displicentiae po učinku izjednačava sa suvremenim jednostranim raskidom ugovora, djelovanja pro futuro. ${ }^{71}$ Smatramo da bi ovo tumačenje bilo prikladno te razlog zbog kojega rimski pravnici pactum displicentiae nisu navodili kao iznimku od pravila, odnosno nisu imali potrebu opravdavati njegovu dopuštenost jer ako je pravni posao čist, purum, nastale su valjane obveze i za kupca i prodavatelja. Ne postoji zapravo potestativni uvjet jer je obveza bezuvjetna te načelo obligatio est vinculum iuris nije narušeno. Štoviše, predajom stvari prodavatelj je ispunio svoju obvezu te bi kupac najčešće postao vlasnikom i sve njegove radnje sa stvari u tom periodu bile su valjane.

69 D. 20, 6, 3: "Ako je stvar prodana i predana, pod uvjetom da do određenog datuma prodavatelj ne dobije bolju ponudu, i prije nego dođe bolja ponuda, kupac založi (ručni zalog - pignus) stvar, Marcel u petoj knjizi svojih Digesta kaže da se založno pravo gasi ako je bolja ponuda pristigla, iako, ako je stvar prodana pod uvjetom da ju kupac može odbiti, on ne misli da će se tada založno pravo ugasiti."

70 Knellwolf, op. cit. u bilj. 3, str. $127-128$.

71 Ibid., str. 133; Diaz Rodriguez, op. cit. u bilj. 3, str. 180. 
Određenu sumnju glede učinka raskida $e x$ nunc, međutim, stvara upotreba riječi inempta u fragmentima o pactum displicentiae, primjerice kod Paula: ${ }^{72}$

D. 41, 4, 2, 5 (Paulus libro 54 ad edictum) Sed et illa emptio pura est, ubi convenit, $u t$, si displicuerit intra diem certum, inempta sit. ${ }^{73}$

Fragment se odnosi na stjecanje dosjelošću pro emptore, pri čemu Paul posebno raspravlja o problemu dosjelosti kod kupoprodaje sklopljene pod odgodnim uvjetom, odnosno uz sporazum o raskidu (D. 41, 4, 2, 3: ...Sed videamus, utrum condicio sit hoc an conventio: si conventio est, magis resolvetur quam implebitur.). Počevši od općenito uvjetovane kupnje u drugom paragrafu, preko lex commissoria u trećem, in diem addictio u četvrtom, u petom se kratko proteže prije izneseno pravilo iz prethodnih dvaju o mogućnosti dosjedanja stvari ako je uglavak koncipiran u raskidnom obliku i na pactum displicentiae. Ključ je u tome da je kupoprodaja bezuvjetna, emptio pura, ako je dogovoreno da će stvar biti nekupljena ako se pokaže nezadovoljavajućom u ugovorenom periodu. Iz značenja riječi inempta moglo bi se tumačiti da bi bila riječ o ex tunc učinku, odnosno da bi se stranke morale vratiti u poziciju kao da nikad nisu sklopile ugovor. ${ }^{74}$ Problem je pak u tome što se u tekstu ne spominje ni povrat plodova ni što slično što bi potvrdilo navedeni zaključak.

Puno važnijim čini nam se Paulovo isključivo svrstavanje pactum displicentiae među conventiones kojima se raskida ugovor, odnosno jasno navođenje da tu nije riječ o uvjetu. Ako nije riječ o uvjetu, onda nema ni problema s potestativnom naravi. Pritom smatramo da ne treba zanemariti ni činjenicu da su u klasičnim tekstovima koji upućuju na odgodni učinak prisutne dvojbe o tome je li kod kupnje gdje se traži odobrenje, placere, riječ o kupoprodaji ili nije, odnosno može li se koristiti actio empti, actio in factum slična njoj ili actio praescriptis verbis. ${ }^{75}$

Osim prikazanog tumačenja koje nam djeluje najuvjerljivijim, u literaturi su izložene i druge teze prema kojima frazu quod sub condicione resolvitur treba

72 Uz Paula, možemo također spomenuti i Ulpijana, koji frazu koristi u raspravi o tome tko može koristiti interdictum quod vi aut clam u D. 43, 24, 11, 13 (Ulpianus libro 71 ad edictum): Si ita praedium venierit, $u t$, si displicuisset, inemptum esset, facilius admittimus interdictum emptorem habere, si modo est in possessione... ("Ako je zemljište prodano sa sporazumom da se prodaja može raskinuti ako se kupcu se ne svidi, mi ćemo priznati da je kupac ovlašten na upotrebu interdikta, pod uvjetom da je posjednik...”).

73 D. 41, 4, 2, 5: "Ali, kupoprodaja je čista/valjana, gdje je dogovoreno da je kupljena stvar, ako se stvar pokaže nezadovoljavajućom unutar dogovorenog roka, nekupljena."

74 Vraćanje stranaka u stanje u kojem su bile posebice zagovaraju: Sintenis, op. cit. u bilj. 2, str. 322 - 323; Kaser, II, op. cit. u bilj. 3, str. 287.

75 Vidi u tekstu citiran D. 19, 5, 20 pr. te ostale fragmente navedene u bilj. 42. 
promatrati na način da je ugovor raskidiv zbog dodatnog sporazuma kao zasebnog pravnog posla, a ne kao uvjeta. Prema jednoj od njih, koju zastupaju Unterholzner i Lardeur, pactum displicentiae bio bi zapravo pactum poenitentiae. ${ }^{76}$ Prema Unterholzneru, a čijem se mišljenju priklonio Lardeur, naime, pactum displicentiae predstavlja svojevrsnu rezervaciju, odnosno mogućnost pokajanja kupca i odustanka od ugovora, međutim on nije isključio i mogućnost da bi mogla biti riječ i o odgodnom uvjetu, ali samo ako je takva formulacija ugovorena u obliku "pogodnosti" za kupca ili prodavatelja. ${ }^{77}$

Drugi oblik interpretacije bio bi da je pactum displicentiae zaseban, novi sporazum, sličan pactum de non petendo, sporazumu stranaka kojim se vjerovnik odriče svoje tražbine, odnosno neformalnoj pogodbi o otpustu duga iz stipulacije. ${ }^{78}$ Takva pogodba nije imala učinak u civilnom pravu s obzirom na to da nije contrarius actus te je pretor stoga pružao zaštitu dužniku u obliku prigovora exceptio pacti conventi. Razlika između pactum de non petendo i kupoprodaje s uglavkom pactum displicentiae, quod sub condicione resolvitur ogleda se u činjenici da bi se neformalni oprost duga trebao, u pravilu, dogoditi nakon proteka određenog vremenskog perioda od samog sklapanja ugovora. Međutim, ni ne inzistirajući na navedenom ${ }^{79}$, veći problem jesu učinci opisanog dodatnog sporazuma. Njegov je osnovni učinak nemogućnost utuživanja tražbine, dok je cilj stranaka kod kupnje na pokus oduzeti učinke sklopljenoj kupoprodaji i vratiti se u stanje u kojem su bile prije sklapanja istog. Također, kod pactum de non petendo bit je $\mathrm{u}$ zaštiti s exceptio, što ne bi bio slučaj i kod pactum displicentiae. U skladu s time i navedena teza čini nam se neprihvatljivom.

Blisko tome, no bolje prilagođeno naravi sinalagmatičnih ugovora, bilo bi tumačenje utemeljeno na pravu na raskid ugovora koje proizlazi iz sporazuma

76 Unterholzner, K. A. D., Quellenmäßige Zusammenstellung der Lehre des römischen Rechts von den Schuldverhältnissen, Bd. 2, Verlag von J. Barth, Leipzig, 1840., str. 223; Lardeur, op. cit. u bilj. 3, str. 7.

77 Unterholzner, ibid.

78 Girard, P. F.; Mayr, R., Geschichte und System des römischen Rechtes (Manuel élémentaire de droit romain), Bd. 2, F. Vahlen, Berlin, 1908., str. 777 - 782.

79 Argument se izvlači iz same logike stvari te se ne nalazi u izvorima, no upitno je koliko je životna situacija u kojoj bi se vjerovnik odmah nakon sklapanja ugovora neformalno odrekao prava tražiti ispunjenje tražbine od dužnika. U literaturi se nalazi tumačenje kako načelno ništa ne brani strankama da to učine te bi se u tom kontekstu zaista moglo govoriti o kupoprodaji s dodanim pactum displicentiae $\mathrm{u}$ obliku dodatnog sporazuma o raskidu ugovora kao pactum de non petendo. Učinak sporazuma morao bi biti uvjetovan, ali bi bila riječ o odgodnoj uvjetovanosti, jer bi se suspendirao njegov destruktivni učinak na osnovni pravni posao kojem je dodan. Ibid. 
stranaka, contrarius consensus. ${ }^{80}$ Naime, kupoprodajni odnos klasičnog prava mogao je kao konsenzualni ugovor prestati samim sporazumom stranaka. Preduvjet za to bilo je da nijedna strana još nije izvršila, odnosno nije počela izvršavati dio svoje činidbe. ${ }^{81}$ Generalno, cilj takvog sporazuma bilo bi ukidanje cjelokupnog obveznopravnog odnosa te povrat u stanje u kojem su stranke bile prije nego su sklopile ugovor.

Svrha koju pružaju uglavak pactum displicentiae i contrarius consensus djeluje usporedivo. Može se pretpostaviti da bi u slučaju izjednačavanja instituta pravo na raskid kupoprodajnog ugovora bilo ugovoreno kao dodatni uglavak samom glavnom ugovoru te da bi takav uglavak po sadržaju bio uvjet koji ima odgodni učinak, što se ogleda u činjenici da klauzula neće proizvoditi pravne učinke sve dok se uvjet nesviđanja ne ispuni. Tumačenje ima nekoliko mana, od kojih je najveća činjenica da konstrukcija sporazumnog raskida ugovora u obliku contrarius consensus zahtijeva da nijedna strana nije izvršila ili počela izvršavati svoju činidbu. ${ }^{82}$ Kad se uzme u obzir da je kupoprodajni ugovor s raskidnim uvjetom često bio definiran kao negotium purum te da je prodavatelj izvršio svoju činidbu, nameće se zaključak da se pactum displicentiae ipak ne bi mogao smatrati oblikom sporazumnog raskida ugovora, contrarius consensus.

Pri ispitivanju mogućih rješenja u literaturi izneseno je i tumačenje kojim se kupnju na pokus izjednačuje s ugovorom o nazadkupnji. ${ }^{83} \mathrm{U}$ rimskom klasičnom pravu takav bi se ugovor sklapao u obliku pacta adiecta naziva pactum de retroemendo ${ }^{84}$, a prema njemu bi se kupac obvezivao da će pod određenim okolnostima ili nakon određenog vremena prodati stvar nazad prodavatelju (ili njegovim nasljednicima) po istoj cijeni ako je on to htio. Sličnost dodanog uglavka o nazadkupnji s uglavkom pactum displicentiae vidljiva je jedino u činjenici da će kod nazadkupnje prodavatelj moći vraćanjem plaćene kupovnine, tj.

80 Cf. Knellwolf, op. cit. u bilj. 3, str. 130 et seq. Više o institutu contrarius consensus vidi u: Knütel, R., Contrarius Consensus. Studien zur Vertragsaufhebung im römischen Recht, Böhlau Verlag, Köln, 1968.; Siber, H., Contrarius consensus, Zeitschrift der Savigny-Stiftung für Rechtsgeschichte, Romanistische Abteilung, vol. 42, 1921., str. 80.

81 Cf. Kaser I, op. cit. u bilj. 3, str. 537 - 538; Chinchilla Imbett, C. A., 'Contrarius consensus': Termination of contract by mutual consent in Roman law, Revista de Derecho Privado, vol. 28, 2015., str. 79 - 126.

82 Cf. Bechmann II, op. cit. u bilj. 2, str. 476.

83 Knellwolf, op. cit. u bilj. 3, str. 131 et seq.; Lardeur, op. cit. u bilj. 3, str. 8.

84 Pakt je prepoznatljiv samo u dvama tekstovima, D. 19, 5, 12 (Proculus libro 11 epistularum) i C. 4, 54, 2 (Imperator Alexander Severus), te Zimmermann stoga zaključuje da bi on bio "practically less important example of pacta appended to contracts of sale.” Cf. Zimmermann, op. cit. u bilj. 5, str. 509 - 510 . 
plaćanjem jednakog iznosa za koji je prodao stvar, tražiti stvar natrag, dok će kod kupoprodaje s dodanim uglavkom pactum displicentiae kupac moći tražiti plaćenu kupovninu s povratom kupljene stvari. Drugim riječima, to je slično pravo, no ovlaštenici su dijametralno suprotne ugovorne strane te bi stoga bilo teško pactum displicentiae izjednačiti s pactum de retroemendo. ${ }^{85}$

\section{ZAKLJUČAK}

Iz tekstova klasičnih pravnika sadržanih u Digestama jasno proizlazi utvrđenost pravila da su potestativni uvjeti ugovoreni u korist uvjetno obvezane strane, tj. oni uvjeti čije je ispunjenje ovisilo samo o volji dužnika, bili nevaljani. Izvori se u prvom redu odnose na stipulaciju, no kako je vidljivo iz analiziranih fragmenata, posebice D. 44, 7, 8, pravilo je bilo šireg značenja te bi se odnosilo i na druge izvore obveza. Glede kupoprodaje to jasno potvrđuje D. 18, 1, 7 pr., kao i konstitucija C. 4, 38, 13. Temeljni razlog navedenoga stava pravnika, kao i carske kancelarije, da uvjet si volam i ugovor sklopljen pod takvim uvjetom nisu bili valjani, ležao je u činjenici da iz ugovora nije proizlazila sigurna obveza dužnika (vinculum iuris) te da vjerovnik nije imao način na koji bi prisilio dužnika na ispunjenje tražbine. Iznimno, kako navodi Ulpijan u D. 18, 1, 7 pr. na primjeru klauzule si rationes domini computasset arbitrio, uvjet koncipiran tako da bi upućivao na potestativnu narav mogao se održati na snazi tumačenjem na način da bi on podrazumijevao objektivni kriterij procjene (arbitrium boni viri), a ne puku subjektivnu ocjenu jedne od strana, u navedenom slučaju kupca.

Pactum displicentiae, uglavak o kupnji na probu prema kojem bi kupac mogao u određenom roku odlučiti o tome sviđa li mu se stvar ili ne sviđa, te ovisno o tome osnažiti ugovor ako je uglavak pripremljen u odgodnom obliku, ili ga raskinuti ako je bio u raskidnom obliku, prema sadržaju bi odgovarao potestativnom uvjetu u korist obvezanika. Problem je, međutim, kako uskladiti postojanje i nesumnjivu dopuštenost pactum displicentiae s pravilom o nevaljanosti potestativnih uvjeta koji ovise samo o volji dužnika. U literaturi je već tijekom 19. stoljeća, sve do današnjih dana, izložen niz tumačenja kojima bi se opravdala ta iznimka te su $\mathrm{u}$ radu analizirane istaknute teze koje se generalno mogu podijeliti s obzirom na to na kojoj se koncepciji uglavka temelje, odgodnoj ili raskidnoj. U njihovoj raščlambi pokazao se niz slabosti, pri čemu na primjer smatramo da tumačenja poput Bechmanova, kako uvjetovana okolnost nije volja ili namjera kupca, već stav o predmetu, ne doprinose utvrđivanju pravne naravi uglavka. Bechmanovo

85 Lardeur, op. cit. u bilj. 3, str. 8. 
razdvajanje volje i sviđanja, kao i objašnjenja pandektista bazirana na teoriji o šepavim pravnim poslovima, teško da se mogu dovesti u vezu s tumačenjima uglavka u djelima rimskih pravnika. Također, ni izjednačavanje pactum displicentiae s pactum de non petendo ili, s druge strane, s pactum de retrovendendo, iako među njima postoji određena sličnost glede cilja koji stranke žele postići, ne čini nam se odgovarajućim načinom pojašnjenja prirode uglavka.

Smatramo da najvjerojatnije rješenje počiva na konstrukciji prema kojoj pactum displicentiae nije bio uvjet, već uglavak o raskidu ugovora dodan kupoprodaji. Temelje ovog shvaćanja možemo pronaći u analiziranim izvorima, u prvom redu u fragmentu D. 20, 6, 3 (Ulpianus libro octavo disputationum), u kojem je utvrđeno da založno pravo zasnovano na predmetu kupljenom na pokus neće prestati njegovim povratom zbog nesviđanja. Učinak ex nunc bio bi usporediv s raskidom ugovora te $\mathrm{u}$ tom slučaju, $\mathrm{s}$ obzirom na to da je ugovor sklopljen bez uvjeta, emptio pura, potestativnost koja proizlazi iz sviđanja nije problem. Ugovor je proizvodio učinke u vremenu testiranja, a koji nastavljaju postojati i nakon raskida. Posljedično, kupac je bio vezan u periodu dok je isprobavao stvar te ne postoji početna nesigurnost koja bi ugrozila sam izvor obveze.

Dogmatski gledano, smatramo da bi raskidno formuliran pactum displicentiae bio u skladu s pravilom o nevaljanosti si volam uvjeta jer bi tada kupac bio vezan kupoprodajnim ugovorom od početka. Iako iz izvora proizlazi zaključak da su kupnju na pokus rimski pravnici formulirali i kao condicio suspensiva i kao emptio pura, quod sub condicione resolvitur, vjerujemo da je upravo potonja varijanta kao češća i nespornija utjecala na to da rimski pravnici pactum displicentiae nisu tumačili kao nevaljani potestativni uvjet.

\section{LITERATURA}

Anić, V., Veliki rječnik hrvatskog jezika, Novi Liber, Zagreb, 2009.

Bechmann, A., Der Kauf nach Gemeinem Recht II, Verlag Von Andreas Deichert, Erlangen, 1884.

Birks, P., The Roman Law of Obligations, OUP, Oxford, 2014.

Boemke, B.; Ulrici, B., BGB Allgemeiner Teil, Springer, Berlin, 2009.

Boras, M.; Margetić, L., Rimsko pravo, Pravni fakultet Zagreb, Zagreb, 1980.

Buckland, W. W., The Roman Law of Slavery: The Condition of the Slave in Private Law from Augustus to Justinian, Cambridge University Press, Cambridge 1908.

Chinchilla Imbett, C. A.,'Contrarius consensus': Termination of contract by mutual consent in Roman law, Revista de Derecho Privado, vol. 28, 2015., str. 79 - 126 
Daube, D., Certainty of Price, u: Daube, D. (ur.), Studies in the Roman Law of Sale, Oxford University Press, Oxford, 1959., str. 9 - 46

De Francisci, P., Synallagma, I, Mattei \& C., Pavia, 1913.

De Francisci, P., Synallagma, II, Mattei \& C., Pavia, 1916.

Diaz Rodriguez, E., De la noción de contrato al pactum displicentiae en derecho romano, Universidad de Oviedo, Oviedo, 1998.

Divković, M., Latinsko-hrvatski rječnik, Naprijed, Zagreb, pretisak 1990.

Du Plessis, H., The Unilateral Determination of Price in Roman law, Fundamina: A Journal of Legal History, vol. 18, br. 1, 2012., str. 15 - 31

Effer-Uhe, D. O., Die Wirkung der condicio im römischen Recht, Nomos, Köln, 2008.

Facciolati, J.; Forcellini, E., Totius latinitas lexicon, vol. 2. D-K, Baldwin et Cradock, London, 1828.

Falcone, G., Obligatio est iuris vinculum, G. Giappichelli, Torino, 2003.

Fitting, H., Ueber den Begriff der Bedingung, Archiv für die civilistische Praxis, vol. 39, 1865., str. $305-350$

Fitting, H., Zur Lehre vom Kauf auf Probe oder aufBesicht, Zeitschrift für das gesamte Handelsrecht und Wirtschaftsrecht, vol. 2, 1859., str. 203 - 282

Fitting, H., Zur Lehre vom Kauf auf Probe oder auf Besicht, Zeitschrift für das gesamte Handelsrecht und Wirtschaftsrech, vol. 5, 1862., str. 79 - 178

Flume, W., Allgemeiner Teil des Bürgerlichen Rechts - Das Rechtsgeschäft, Springer, Berlin, 1979.

Frier, B. (ur.); Blume, F. (pr.), Codex Justinianus, vol. 2, Cambridge University Press, Cambridge, 2016.

Frier, B., Roman Law and the Wine Trade: The problem of 'Vinegar Sold as Wine', Zeitschrift der Savigny-Stiftung für Rechtsgeschichte, Romanistische Abteilung, vol. 100, 1983., str. $257-296$

Girard, P. F.; Mayr, R., Geschichte und System des römischen Rechtes (Manuel élémentaire de droit romain), Bd. 2, F. Vahlen, Berlin, 1908.

Goldschmidt, J., Der Kauf auf Probe oder Besicht, Zeitschrift für das gesamte Handelsrecht und Wirtschaftsrecht, vol. 1, 1858., str. 66 - 132, 262 - 375

Hamza, G., Zur Frage der gewillkürten Stellvertretung im klassischen römischen Recht, Annales U. Sci. Budapestinensis Rolando Eotvos Nominatae, vol. 19, 1979., str. $19-42$

Harder, M., Weinkauf und Weinprobe im römischen Recht, u: Lutter, M. et al. (ur.), Festschrift für Johannes Bärmann zum 70. Geburtstag, C. H. Beck, München, 1975., str. 17 - 30 
Hasenhöhrl, V., Das österreichische Obligationenrecht in systematischer Darstellung, vol. 1, Manz, Wien, 1892.

Heumann, H.; Seckel, E., Handlexikon zu den Quellen des römischen Rechts, Verlag von Gustav Fisher, Jena, 1891.

Horvat, M., Rimsko pravo, Pravni fakultet Zagreb, Zagreb, 2002.

Jakab, E., Riskomanagement beim Wienkauf, Periculum und Praxis im Imperium Romanum, C. H. Beck, München, 2009.

Karlović, T., Liber casuum, Priručnik za vježbe iz rimskog obveznog prava, Pravni fakultet Sveučilišta u Zagrebu, Zagreb, 2017.

Kaser, M., Das Römische Privatrecht I, C. H. Beck, München, 1971.

Kaser, M., Das Römische Privatrecht II, C. H. Beck, München, 1971.

Kaser, M., Stellvertretung und notwendige Entgeltlichkeit, Zeitschrift der Savigny-Stiftung für Rechtsgeschichte, Romanistische Abteilung, vol. 91, 1974., str. 146-204.

Keller, F. L., Pandekten, II, Bernhard Tauchnitz, Leipzig, 1866.

Klinck, F., Zur Bedeutung des Wortes procurator in den Quellen des klassischen Rechts, Zeitschrift der Savigny-Stiftung für Rechtsgeschichte, Romanistische Abteilung, vol. 124, 2007., str. 25 - 53

Knellwolf, M., Zur Konstruktion des Kaufes auf Probe, Die Gefallensbedingung und ihr Verhältnis zu Wollensbedingung, Resolutivbedingung und Rücktrittsrecht, doktorska disertacija, Schulthess Polygraphischer Verlag AG, Zürich, 1987.

Knütel, R., Contrarius Consensus. Studien zur Vertragsaufhebung im römischen Recht, Böhlau Verlag, Köln, 1968.

Lardeur, G., Droit Romain: Du Pactum Displicentiae, Droit français: Du contrat d'édition en matière littéraire, doktorska disertacija, Pariz, 1893., Bibliolife (pretisak) 2009.

Lenel, O., Paligenesia Iuris Civils, vol. 2, Bernhard Tauchnitz, Leipzig, 1889.

Leonard, R., Condicio, u: Paulys Realencyclopädie der classischen Altertumswissenschaft, IV, 1, 1900., str. $844-847$

Levy, E., Zu den Rücktrittsvorbehalten des römischen Kaufs, u: Levy, E., Gesammelte Schriften, vol. 2, Böhlau, Köln, 1963., str. 261 - 286

Lewis, C. T., An Elementary Latin Dictionary, American Book Company, New York, 1890. (dostupno online)

Mackintosh, J., The Roman Law of Sale with modern illustrations, T. \& T. Clark Law Publishers, Edinburgh, 1907.

Marević, I., Hrvatsko - latinski enciklopedijski rječnik, II. svezak, Školska knjiga, Zagreb, 1997. 
Misera, K., Der Kauf auf Probe, u: Temporini, H.; Haase, W. (ur.), Aufstieg und Niedergang der römischen Welt, vol. II, 14, 1982., str. 525 - 577

Monier, R., Manuel Élémentaire de Droit Romain, Tome II (Les Obligations), Éditions Domat Montchrestien, Pariz, 1948.

Moyle, J. B., The contract of sale in the Civil Law with references to the Laws of England, Scotland and France, Clarendon Press, Oxford, 1892.

Olszak, N., Emptio Ad Gustum: La Vente a la Degustation, de l'Antiquite a l'Article $1587 d u$ Code Civil, Tijdschrift voor Rechtsgeschiedenis, vol. 58, 1990., str. $361-387$

Pennitz, M., Die Gefahrtragung beim Weinverkauf im klassischen römischen Recht, Tijdschrift voor Rechtsgeschiedenis, vol. 62, 1994., str. 251 - 296

Peters, F., Die Rücktrittsvorbehalte des Römischen Kaufrechts, Böhlau Verlag, Wien, 1973.

Petranović, A., Obligationes Iuris Romani, Pravni fakultet Sveučilišta u Rijeci, Rijeka, 2010.

Petranović, A., Uvjetovani konsenzus i rimska uvjetna kupoprodaja, Zbornik Pravnog fakulteta Sveučilišta u Rijeci, vol. 28, br. 2, 2007., str. 1219 - 1238

Petz, B. et al., Psihologijski rječnik, Slap, Zagreb, 2005.

Pókecz Kovács, A., Rücktrittsvorbehalt und pactum displicentiae (Ulp.D.19.5.20pr.), Revue internationale des droits de 1 antiquite, vol. 58, 2011., str. 315 - 337

Romac, A., Izvori rimskog prava, Infromator, Zagreb, 1973.

Romac, A., Justinijan, Institucije, Latina et Graeca, Zagreb, 1994.

Savigny, F. C., System des heutigen römischen Rechts III, Veit und Comp, Berlin, 1840.

Siber, H., Contrarius consensus, Zeitschrift der Savigny-Stiftung für Rechtsgeschichte, Romanistische Abteilung, vol. 42, 1921., str. 68 - 102

Sieg, H., Quellenkritische Studien zur Bessergebotsklausel (in diem addictio) im römischen Kaufrecht, Friederichsen, de Gruyter \& Co. m.b.h., Hamburg, 1933.

Sintenis, C. F. F., Das practische gemeine Civilrecht Band 2: Das Obligationenrecht, Carl Focke, Leipzig, 1847.

Talamanca, M., Istituzioni di Diritto Romano, Dott. A. Giuffrè Editore, Milano, 1990.

Unger, J., Das Versprechen als Verpflichtungsgrund, Zeitschrift für das privat- und öffentliche Recht der Gegenwart, Bd. 1, 1874., str. 357 - 374

Unterholzner, K. A. D., Quellenmäßige Zusammenstellung der Lehre des römischen Rechts von den Schuldverhältnissen, Bd. 2, Verlag von J. Barth, Leipzig, 1840. 
Wacke, A., Dig. 19,5,20 pr.: Ein Siegespreis auffremden Pferden. Zur Gewinn-Ablieferungspflicht beim Kauf auf Probe, Zeitschrift der Savigny-Stiftung für Rechtsgeschichte, Romanistische Abteilung, vol. 119, 2002., str. 359 - 380

Watson, A. (ur.), The Digest of Justinian, vol. 1, Univeristy of Pennsylvania Press, Philadelphia, 1985.

Watson, A., The Law of Obligations in Late Roman Republic, Clarendon Press, Oxford, 1965.

Wieacker, F., Lex Commissoria: Erfüllungszwang und Widerruf im Römischen Kaufrecht, Springer, Berlin, 1932.

Windscheid, B., Lehrbuch des Pandektenrechts, vol. 1 i 2, 5. Aufl., Ebner \& Seubert, Stuttgart, 1879.

Windscheid, B., Lehrbuch des Pandektenrechts, vol. 1, M. Rütten \& Loening, Frankfurt am Main, 1887.

Wlassak, M., Arbiter, u: Paulys Realencyclopädie der classischen Altertumswissenschaft, II, 1, 1895., str. $412-415$

Wolf, J. G., Error im römischen Vertragsrecht, Böhlau, Köln, 1961.

Yaron, R., Sale of Wine, u: Daube, D. (ur.), Studies in the Roman Law of Sale, Clarendon Press, Oxford, 1959., str. $71-78$

Zerres, T., Bürgerliches Recht: Eine Einführung in das Zivilrecht und die Grundzüge des Zivilprozessrechts, Springer, Heidelberg, 2010.

Zimmermann, R., The Law of Obligations. Roman Foundations of the Civilian Tradition, Oxford University Press, Oxford, 1996.

Zulueta, F. de, The Roman Law of Sale, Introduction and Select Texts, Oxford University Press, London, 1945. 
Summary

\section{Marko Sukačić *}

\section{INVALIDITY OF POTESTATIVE CONDITIONS IN FAVOUR OF DEBTOR AND PACTUM DISPLICENTIAE}

The author in this paper analyses the problem of potestative conditions in favour of the conditionally obligated contractual party, on the example of pactum displicentiae, a provision of a sales contract by which the buyer could unilaterally terminate the contract if he or she is not pleased with the purchased item. A presentation of the Digest sources on the invalidity of potestative conditions in favour of the conditionally obligated contractual party, is followed by an analysis of a potentially valid potestative condition. The next part of the paper contains a study of the general characteristics of pactum displicentiae, with an emphasis on the fact that it represents a potestative condition. Taking into account the rule on invalidity of a condition si volam, the paper presents some interpretations by Romanists who are trying to justify the existence of pactum displicentiae. The last part of the paper consists of an analysis of the interpretation that pactum displicentiae is not a condition, but the right to terminate the contract.

Keywords: si volam, sale on approval, pactum displicentiae, potestative condition, Roman law

* Marko Sukačić, Ph. D., Assistant, Faculty of Law, Josip Juraj Strossmayer University of Osijek, Stjepana Radića 13, Osijek; msukacic@pravos.hr;

ORCID ID: orcid.org/0000-0001-9113-7421 